\title{
THE IMMUNOEXPRESSION OF GLOMERULAR NF- $\kappa$ B IN PROTEINURIC PATIENTS WITH PROLIFERATIVE AND NON-PROLIFERATIVE GLOMERULOPATHIES
}

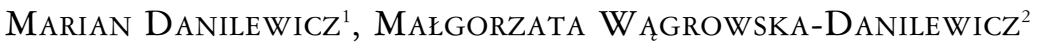 \\ ${ }^{1}$ Department of Pathology, Medical University of Lodz, Lodz, Poland \\ ${ }^{2}$ Department of Nephropathology, Medical University of Lodz, Lodz, Poland
}

\begin{abstract}
Recent studies suggest that NF- $\mathrm{KB}$ activation plays an essential role in the activation of mesangial cells and macrophages through the transcriptional induction of inflammatory mediators of glomerular inflammation and injury. The aim of the present study was to determine, using an image analysis system, glomerular immunoexpression of NF- $\mathrm{kB}$ (nuclear translocation of p65) in proteinuric patients with proliferative and non-proliferative glomerulopathies. Thirty-six proteinuric patients with idiopathic proliferative glomerulopathies (PG group) and 28 proteinuric participants with non-proliferative glomerulopathies (NPG group) were examined by percutaneous renal biopsy. As a control 12 biopsy specimens of the kidneys removed because of trauma were used. In the PG group the mean values of the glomerular immunoexpression of NF- $\mathrm{KB}$ were significantly increased as compared to both NPG patients and controls. In the PG but not in the MPG group glomerular immunoexpression of NF- $\mathrm{\kappa B}$ was significantly positively correlated with the degree of proteinuria. Moreover, in the PG group glomerular immunoexpression of NF-kB was positively correlated with the mesangial cells, mesangial area and glomerular monocytes/macrophages. In conclusion, our results strongly suggest a role of NF- $\kappa \mathrm{B}$ in glomerular injury in proteinuric patients with proliferative glomerulopathies.
\end{abstract}

Key words: NF- $\mathrm{B}$, proteinuric patients, glomerulonephritis.

\section{Introduction}

Transcription nuclear factor $\kappa \mathrm{B}(\mathrm{NF}-\kappa \mathrm{B})$ is a pleiotropic transcription factor regulating the gene expression of several adhesion molecules, cytokines and chemotactic proteins involved in inflammation, immune response and cell proliferation [1-3]. It is a protein present as a homodimer or heterodimer of five members of the NF- $\kappa \mathrm{B} /$ Rel family. The most common dimer in many cell types is composed of subunits p 50 and p65 [4-6]. This dimer is retained in an inactive form within the cytoplasm through non-covalent binding to inhibitory proteins called inhibitory $\kappa \mathrm{B}(\mathrm{I} \kappa \mathrm{B})$. When activated by cytokines, mitogens, viruses or cell injury it moves to the nucleus, binds DNA and influences the transcription of specific genes involved in inflammation such as cytokines and adhesion molecules; hence, it is present in a variety of chronic inflammatory disorders $[7,8]$. Increasing data also suggest that NF- $\kappa \mathrm{B}$ plays a pivotal role in many glomerulopathies, especially immune-mediated $[9,10]$. Immune complex formation and deposition in the kidney result in glomerular inflammation with recruitment of leukocytes, and the activation and proliferation of resident renal cells. However, cellular and molecular mechanisms underlying glomerular cell activation are not yet fully understood in human glomerulopathies [1]. Recent studies suggest that NF- $\kappa \mathrm{B}$ activation plays an essential role in the activation of mesangial cells and macrophages through the transcriptional induction of 
inflammatory mediators of glomerular inflammation and injury $[10,11]$.

In view of the above, the aim of the present study was to determine glomerular immunoexpression of $\mathrm{NF}-\kappa \mathrm{B}$ (nuclear translocation of $\mathrm{p} 65$ ) in proteinuric patients with proliferative and non-proliferative glomerulopathies. Another purpose of this study was to examine the possible relationship between NF- $\mathrm{NB}$ immunoexpression and proteinuria, mesangial proliferation as well as glomerular inflammatory infiltrates.

\section{Material and methods}

\section{Patients}

Thirty-six patients with idiopathic proliferative glomerulopathies (PG group) who presented with proteinuria or nephrotic syndrome (mean age 39.5 $\pm 12.6)$ and 28 participants with non-proliferative glomerulopathies (NPG group) who presented with proteinuria or nephrotic syndrome (mean age 34.2 $\pm 14.7)$ were examined by percutaneous renal biopsy. The PG group included 14 cases with mesangiocapillary glomerulonephritis, 16 patients with $\operatorname{IgA}$ nephropathy and 6 with mesangial proliferative IgM glomerulopathy, whereas the NPG group consisted of 20 cases with membranous glomerulopathy and 8 with minimal changes. In all cases, diagnosis was based on characteristic findings by light microscopy (sections stained with hematoxylin and eosin, Masson-Trichrome, Jones' silver impregnation and periodic acid-Schiff followed by Alcian blue) as well as immunofluorescence (using antibodies against Ig A, IgG, IgM, C3, C1q and light chains $\lambda$ and $\kappa)$. Moreover, in all patients electron microscopy was performed using standard protocols. Thickness of each section was controlled according to the method described by Weibel [12]. Most of our patients were middle-aged. Male predominance was noticeable in both PG and NPG groups. At the time of renal biopsy in the PG group 12 participants had nephrotic syndrome and 24 had proteinuria, whereas in the NPG group nephrotic syndrome was noted in 20 patients and proteinuria in 8 . Hematuria accompanied proteinuria in 23 PG and 11 NPG cases. Clinical renal impairment (serum creatinine greater than $1.5 \mathrm{mg} / \mathrm{dl}$ ) was noted in 6 PG and 2 NPG patients. Elevated blood pressure was found in 11 PG and 2 NPG individuals. As a control 12 biopsy specimens of the kidneys removed because of trauma were used (the male to female ratio was 8:4, the mean age was $39.1 \pm 8.1$ ). None of the persons from whom renal tissue originated were known to have had previous or current renal disease. Before the quantitative examinations were carried out, all control specimens were histologically examined by a nephropathologist and found to be normal renal tissue.

\section{Immunohistochemistry}

Paraffin sections were mounted onto superfrost slides, deparaffinized, then treated in a microwave oven in a solution of citrate buffer, $\mathrm{pH} 6.0$ for $20 \mathrm{~min}$ and transferred to distilled water. Endogenous peroxidase activity was blocked by $3 \%$ hydrogen peroxide in distilled water for $5 \mathrm{~min}$, and then sections were rinsed with Trisbuffered saline (TBS, DakoCytomation, Denmark) and incubated with: polyclonal rabbit-anti-human NF- $\mathrm{NB}$ p65 (Immuno-Biological Laboratories Co., Ltd., dilution $5 \mu \mathrm{g} / \mathrm{ml}$ ), monoclonal mouse anti-human CD68 antibody (Clone KP-1, DakoCytomation, Denmark, dilution 1 : 100), monoclonal mouse anti-human CD3 T cell antibody (Clone PC3/188A, DakoCytomation, Denmark, dilution $1: 50)$ and monoclonal mouse antihuman CD20 B cell antibody (Clone L-26, DakoCytomation, Denmark, dilution 1 : 200). Afterwards LSAB +/HRP Universal kit (DakoCytomation, Denmark) prepared according to the instructions of the manufacturer was used. Visualization was performed by incubating the sections in a solution of $0.5 \mathrm{mg} \mathrm{3,3'-}$ diaminobenzidine (DakoCytomation, Denmark), per $\mathrm{ml}$ Tris- $\mathrm{HCl}$ buffer, $\mathrm{pH} 7.6$, containing $0.02 \%$ hydrogen peroxide, for $10 \mathrm{~min}$. After washing, the sections were counter-stained with hematoxylin and coverslipped. For each antibody and for each sample a negative control was processed. Negative controls were carried out by incubation in the absence of the primary antibody and always yielded negative results.

\section{Morphometry}

Histological morphometry was performed by means of an image analysis system consisting of a PC equipped with a Pentagram graphical tablet, Indeo Fast card (frame grabber, true-color, real-time), produced by Indeo (Taiwan), and Panasonic color TV camera (Japan) coupled to a Carl Zeiss microscope (Germany). This system was programmed (MultiScan 8.08 software, produced by Computer Scanning Systems, Poland) to calculate the number of objects (semiautomatic function) and the surface area of a structure using a stereological net (with regulated number of points). The colored microscopic images were saved serially in the memory of the computer, and then quantitative examinations were carried out.

In all available glomeruli the immunoexpression of $\mathrm{NF}-\kappa \mathrm{B}$, glomerular monocytes/macrophages, $\mathrm{T}$ lymphocytes and $B$ lymphocytes were determined by counting p $65+, \mathrm{CD} 68+, \mathrm{CD} 3$ and CD20+ cells (semiautomatic function). The same method was used for counting glomerular mesangial cells (in PAS-Alcian blue staining). The results were expressed as a mean number of immunopositive cells or mesangial cells per glomerular cross-section.

Mesangial area per cent of total glomerular area (in PAS-Alcian blue staining) was measured using the point 


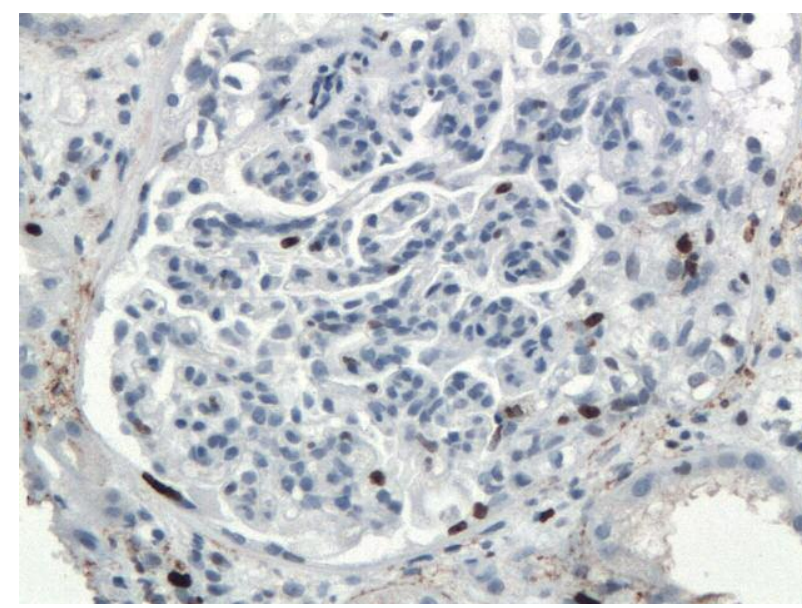

Fig. 1. PG group (mesangiocapillary glomerulonephritis). The immunoexpression of NF- $\mathrm{KB}$ in glomerular mesangial and epithelial cells. Magnification $400 \times$

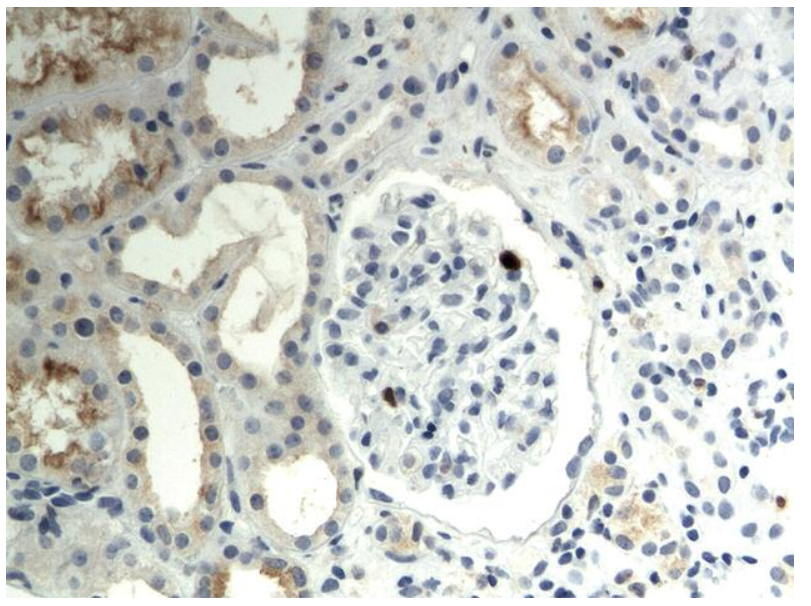

Fig. 2. NPG group (minimal change disease). The immunoexpression of NF-kB in some mesangial cells. Magnification 200×

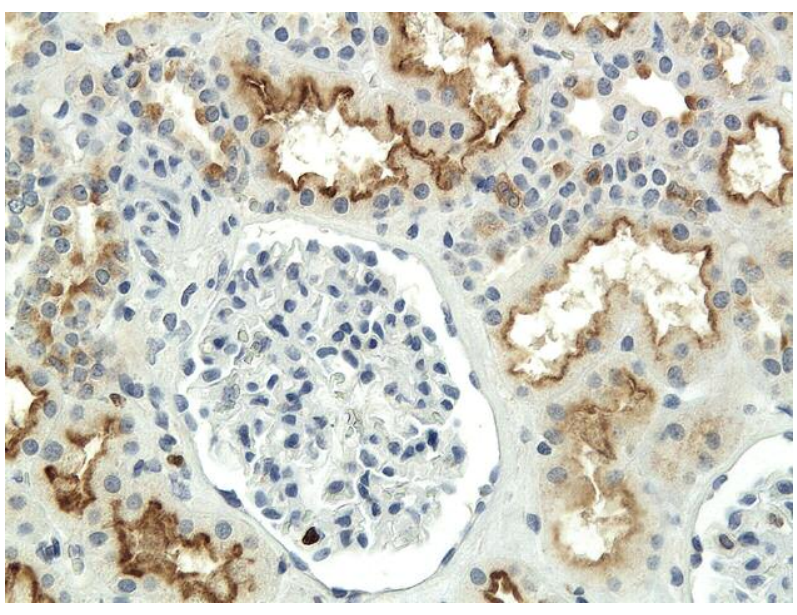

Fig. 3. Control group. Only one immunopositive cell within the glomerulus is seen. Magnification $200 \times$

counting method, which is an adaptation of the principles of Weibel [12]. The point spacing was $16 \mu \mathrm{m}$. The total number of the points of a net was 169 , and total area was $36864 \mathrm{sq} . \mu \mathrm{m}$. The percentage of mesan- gial area was an expression of the number of points overlying this structure as a percentage of the total points counted.

\section{Statistical methods}

Differences between groups were tested using unpaired Student's t-test preceded by evaluation of normality and Levene's test. The Mann-Whitney U test was used where appropriate. Correlation coefficients were calculated using Spearman's method. Results were considered statistically significant if $\mathrm{p}<0.05$.

\section{Results}

Clinical features of the patients at the time of biopsy are given in Table I. The glomerular immunoexpression of NF- $\mathrm{NB}$ (mainly in mesangial cells but also in some endothelial and epithelial cells) in both PG and NPG groups with proteinuria was exclusively nuclear (Fig. 1 and Fig. 2.). In controls nuclear glomerular immunoexpression of NF- $\mathrm{KB}$ was very weak (Fig. 3). Nuclear immunoexpression of NF- $\mathrm{kB}$ was also seen in tubular epithelial cells and interstitial infiltrates, but for the present study it was not taken into consideration. A morphometric comparison of glomerular immunoexpression of NF- $\mathrm{\kappa B}$, mesangial parameters and glomerular inflammatory cells appears in Table II. In the PG group the mean values of the glomerular immunoexpression of NF- $\kappa \mathrm{B}$, mesangial cells, mesangial area and interstitial infiltrates $(\mathrm{CD} 68+, \mathrm{CD} 3+$ and CD20+ cells) were significantly increased as compared to both NPG patients and controls. A comparison of NPG patients and controls revealed that only the immunoexpression of NF- $\mathrm{KB}$ was significantly increased in the NPG group. The mesangial cells, mesangial area and glomerular monocytes/macrophages as well as $\mathrm{T}$ and $\mathrm{B}$ lymphocytes did not differ significantly in these groups. In the PG but not in the MPG group glomerular immunoexpression of $\mathrm{NF}-\mathrm{\kappa B}$ was significantly positively correlated with the degree of proteinuria. Moreover, in the PG group glomerular immunoexpression of NF- $\mathrm{KB}$ was positively correlated with the mesangial cells, mesangial area and glomerular monocytes/macrophages. In controls all correlations were weak and not significant (Table III).

\section{Discussion}

$\mathrm{NF}-\kappa \mathrm{B}$ regulates the gene expression of several cytokines and matrix proteins that are involved in inflammation $[13,14]$. In the present study we revealed that glomerular immunoexpression of NF- $\mathrm{KB}$ was significantly increased in PG proteinuric patients as compared to the NPG group and controls. NF- $\kappa \mathrm{B}$ activation has been observed in several experimental and human glomerular diseases $\{1,15,16]$. Sakurai $e t$ al. noted increased activation of NF- $\mathrm{kB}$ in rat glomeruli shortly 
Table I. Clinical and laboratory findings at the time of biopsy in cases with proteinuric proliferative and non-proliferative glomerulopathies

\begin{tabular}{|c|c|c|c|c|c|c|c|c|}
\hline \multirow{3}{*}{$\begin{array}{l}\text { NUMBER } \\
\text { OF CASES }\end{array}$} & \multirow{3}{*}{$\begin{array}{c}\text { GENDER } \\
(\mathrm{M} / \mathrm{F})\end{array}$} & \multirow{3}{*}{$\begin{array}{l}\text { MICRO- } \\
\text { HEMA- } \\
\text { TURIA } \\
\end{array}$} & \multirow{3}{*}{$\begin{array}{l}\text { GROSS } \\
\text { HEMA- } \\
\text { TURIA }\end{array}$} & \multicolumn{2}{|c|}{ Proteinuria } & \multirow{3}{*}{$\begin{array}{l}\text { NEPHROTIC } \\
\text { SYNDROME }\end{array}$} & \multirow{3}{*}{$\begin{array}{c}\text { RENAL } \\
\text { FUNCTION } \\
\text { IMPAIRMENT* }\end{array}$} & \multirow{3}{*}{$\begin{array}{c}\text { HYPERTENSION } \\
(>90 / 160)\end{array}$} \\
\hline & & & & $1-2$ & $2-3.5$ & & & \\
\hline & & & & $\mathrm{G} / 24 \mathrm{H}$ & $\mathrm{G} / 24 \mathrm{H}$ & & & \\
\hline $\begin{array}{l}\text { proliferative } \\
\text { glomerulopathies } \\
(\mathrm{n}=36)\end{array}$ & $22 / 14$ & 12 & 11 & 10 & 14 & 12 & 6 & 11 \\
\hline $\begin{array}{l}\text { non-proliferative } \\
\text { glomerulopathies } \\
(\mathrm{n}=28)\end{array}$ & $16 / 12$ & 6 & 5 & 3 & 5 & 20 & 2 & 2 \\
\hline
\end{tabular}

Table II. Morphometric data of glomerular immunoexpression of NF-kB, mesangial parameters and glomerular inflammatory cells in proteinuric cases with proliferative and non-proliferative glomerulopathies as well as in controls

\begin{tabular}{|c|c|c|c|c|}
\hline & $\begin{array}{l}\text { Proliferative } \\
\text { GLOMERULO- } \\
\text { PATHIES } \\
(\mathrm{N}=36)\end{array}$ & $\begin{array}{c}\text { NON-PROLIFERA- } \\
\text { TIVE GLOMERULO } \\
\text { PATHIES } \\
(\mathrm{N}=28)\end{array}$ & $\begin{array}{l}\text { CONTROLS } \\
(\mathrm{N}=12)\end{array}$ & $P$ Value \\
\hline NF- $\kappa \mathrm{B}$ immunopositive & $2.3 \pm 2.6$ & $0.88 \pm 0.7$ & $0.27 \pm 0.1$ & $<0.007^{\mathrm{a}}, \quad<0.02^{\mathrm{b}},<0.006^{\mathrm{c}}$ \\
\hline $\begin{array}{l}\text { cells/glomerular cross-section } \\
\text { mesangial cells/glomerular } \\
\text { cross-section }\end{array}$ & $26.2 \pm 11.3$ & $17.4 \pm 7.1$ & $15.2 \pm 6.3$ & $<0.001^{\mathrm{a}},<0.003^{\mathrm{b}},=0.35^{\mathrm{c}}$ \\
\hline $\begin{array}{l}\text { mesangium (\% of total } \\
\text { glomerular area) }\end{array}$ & $12.6 \pm 3.8$ & $9.2 \pm 1.4$ & $8.7 \pm 1.1$ & $<0.001^{\mathrm{a}},<0.002^{\mathrm{b}},=0.27^{\mathrm{c}}$ \\
\hline $\begin{array}{l}\text { CD } 68+\text { cells/glomerular } \\
\text { cross-section }\end{array}$ & $2.43 \pm 1.7$ & $1.28 \pm 0.6$ & $0.98 \pm 0.4$ & $<0.002^{\mathrm{a}},<0.006^{\mathrm{b}},=0.12^{\mathrm{c}}$ \\
\hline $\begin{array}{l}\mathrm{CD} 3+\text { cells/glomerular } \\
\text { cross-section }\end{array}$ & $1.08 \pm 0.65$ & $0.32 \pm 0.43$ & $0.21 \pm 0.13$ & $<0.001^{\mathrm{a}},<0.001^{\mathrm{b}},=0.39^{\mathrm{c}}$ \\
\hline $\begin{array}{l}\text { CD } 20+\text { cells/glomerular } \\
\text { cross-section }\end{array}$ & $1.22 \pm 0.71$ & $0.15 \pm 0.11$ & $0.11 \pm 0.10$ & $<0.001^{\mathrm{a}},<0.001^{\mathrm{b}},=0.28^{\mathrm{c}}$ \\
\hline
\end{tabular}

Table III. Spearman rank order correlations between glomerular immunoexpression of NF- $\mathrm{B}$ and proteinuria, mesangial cells, mesangial area as well as glomerular infiltrates

\begin{tabular}{|c|c|c|c|}
\hline PAIR of VARIABLES & $\begin{array}{c}\text { Proliferative } \\
\text { GLOMERUlopathies } \\
\quad(\mathrm{N}=36) \\
\end{array}$ & $\begin{array}{l}\text { NON-PROLIFERATIVE } \\
\text { GLOMERULOPATHIES } \\
\qquad(\mathrm{N}=28)\end{array}$ & $\begin{array}{l}\text { CONTROLS } \\
(\mathrm{N}=12)\end{array}$ \\
\hline $\begin{array}{l}\text { glomerular immunoexpression } \\
\text { of NF- } \kappa \mathrm{B} \text { and proteinuria }\end{array}$ & $\mathrm{r}=0.51, \mathrm{p}<0.002$ & $\mathrm{r}=0.355, \mathrm{p}=0.066(\mathrm{NS})$ & - \\
\hline $\begin{array}{l}\text { glomerular immunoexpression } \\
\text { of NF- } \mathrm{B} \text { and mesangial cells }\end{array}$ & $\mathrm{r}=-0.38, \mathrm{p}<0.03$ & $\mathrm{r}=0.23, \mathrm{p}=0.24(\mathrm{NS})$ & $\mathrm{r}=0.34, \mathrm{p}=0.29(\mathrm{NS})$ \\
\hline $\begin{array}{l}\text { glomerular immunoexpression } \\
\text { of NF- } \kappa \mathrm{B} \text { and mesangial area }\end{array}$ & $\mathrm{r}=-0.46, \mathrm{p}<0.005$ & $\mathrm{r}=0.23, \mathrm{p}=0.24(\mathrm{NS})$ & $\mathrm{r}=0.17, \mathrm{p}=0.59(\mathrm{NS})$ \\
\hline $\begin{array}{l}\text { glomerular immunoexpression } \\
\text { of NF- } \kappa \mathrm{B} \text { and glomerular } \\
\text { CD } 68+\text { cells }\end{array}$ & $\mathrm{r}=-0.58, \mathrm{p}<0.001$ & $\mathrm{r}=0.3232, \mathrm{p}=0.099(\mathrm{NS})$ & $\mathrm{r}=0.41, \mathrm{p}=0.18(\mathrm{NS})$ \\
\hline $\begin{array}{l}\text { glomerular immunoexpression } \\
\text { of NF- } \kappa \text { B and glomerular } \\
\text { CD3 }+ \text { cells }\end{array}$ & $\mathrm{r}=-0.29, \mathrm{p}=0.08(\mathrm{NS})$ & $\mathrm{r}=0.16, \mathrm{p}=0.41(\mathrm{NS})$ & $\mathrm{r}=0.09, \mathrm{p}=0.78(\mathrm{NS})$ \\
\hline $\begin{array}{l}\text { glomerular immunoexpression } \\
\text { of NF- } \kappa \mathrm{B} \text { and glomerular } \\
\text { CD } 20+\text { cells }\end{array}$ & $\mathrm{r}=0.18, \mathrm{p}=0.29(\mathrm{NS})$ & $\mathrm{r}=0.19, \mathrm{p}=0.33(\mathrm{NS})$ & $\mathrm{r}=0.06, \mathrm{p}=0.85(\mathrm{NS})$ \\
\hline
\end{tabular}


after nephrotoxic serum administration and the development of proteinuria. The effect peaked at days 3 to 5 and lasted about two weeks [17]. Our data support this observation as we found a significant positive correlation between glomerular immunoexpression of $\mathrm{NF}-\kappa \mathrm{B}$ and proteinuria. Of note, this correlation in proteinuric NPG patients was also positive but not significant. Contrary to us, Zheng et al. showed a positive correlation of glomerular NF- $\mathrm{KB}$ also in the non-proliferative group. However, in this study glomerular NF- $\mathrm{kB}$ immunoexpression was confined only to podocytes $[1]$. Our observations may suggest different mechanisms of proteinuria in proliferative and non-proliferative glomerulopathies. Although in our study, as may be expected, mesangial parameters and glomerular inflammatory infiltrates were significantly greater in the PG group in comparison to NPG patients and controls, the correlative study gave an interesting insight into the role of NF- $\mathrm{kB}$ in glomerular proliferative changes. In proliferative glomerulopathies we observed significant positive correlations between glomerular immunoexpression of NF- $\mathrm{KB}$ and both mesangial cells and mesangial area, whereas these correlations were in NPG patients and controls weak and not significant. Similarly, Zheng et al. found a positive significant correlation between glomerular NF- $\mathrm{\kappa B}$ activation and activity index in patients with lupus nephritis [1], whereas Peng et al. revealed the NF- $\mathrm{KB}$ inflammatory signaling pathway in rat glomerular mesangial cells cultured under high glucose [18]. In IgA nephropathy glomerular NF- $\mathrm{KB}$ expression correlated with progression of tissue injury [15]. It was also revealed that increased NF- $\mathrm{KB}$ activation in mesangial cells correlates with increased expression of a variety of inflammatory genes such as interleukins IL- $1 \beta$ IL- 6 and IL-8, tumor necrosis factor $\alpha$ (TNF- $\alpha$ ) monocyte chemoattractant protein-1 (MCP-1), interferon invasive protein-10 (IP-10), and inducible nitric oxide synthase $[2,10,19-23]$. In addition to the proinflammatory actions of NF- $\mathrm{KB}$, some data, similarly as our study, support a role for NF- $\mathrm{NB}$ in the control of mesangial cell proliferation [2, 24-28].

Another important finding in the present study was that in PG but not in NPG and control patients a significant positive correlation existed between glomerular immunoexpression of NF-kB and glomerular CD $68+$ cells. Similarly, Zheng et al. found that the degree of glomerular macrophage infiltration was positively correlated with the number of mesangial and endothelial cells positive for NF-кB [1]. Moreover, Hisada et al. observed in cultured cells close interaction between mesangial cells and monocytes/macrophages through NF-кB activation [29]. These observations suggest that overexpression of $\mathrm{NF}-\mathrm{KB}$ in glomerular cells may play a pathogenic role in glomerular inflammation and injury in proliferative glomerulopathies.
On the other hand, we found that correlations between glomerular immunoexpression of $\mathrm{NF}-\kappa \mathrm{B}$ and glomerular $\mathrm{T}$ lymphocytes and $\mathrm{B}$ lymphocytes were weak and not significant in all groups. These results may suggest that in glomeruli $\mathrm{CD} 3+$ and $\mathrm{CD} 20+$ cells are not involved in the NF- $\mathrm{kB}$ signaling pathway in human glomerulopathies.

In conclusion, our results strongly suggest a role of $\mathrm{NF}-\kappa \mathrm{B}$ in glomerular injury in proteinuric patients with proliferative glomerulopathies.

This work was supported by Medical University of Łódź grant 503/6-038-01/503-01.

\section{References}

1. Zheng L, Sinniah R, Hsu SI. In situ glomerular expression of activated NF-kappaB in human lupus nephritis and other non-proliferative proteinuric glomerulopathy. Virchows Arch 2006; 448: 172-183.

2. Guijarro C, Egido J.Transcription factor-kappa B (NF-kappa B) and renal disease. Kidney Int 2001; 59: 415-424.

3. Li Q, Verma IM. NF-kappaB regulation in the immune system. Nat Rev Immunol 2002; 2: 725-734.

4. Baldwin AS. The NF- $\kappa \mathrm{B}$ and $1 \kappa \mathrm{B}$ proteins: New discoveries and insights. Annu Rev Immunol 1996; 14: 649-681.

5. Ghosh S, May MJ, Kopp EB. NF-кB and Rel proteins: evolutionarily conserved mediators of immune responses. Annu Rev Immunol 1998; 16: 225-260.

6. Grilli M, Chiu JJ, Lenardo MJ. NF- $\kappa B$ and Rel: participants in a multiform transcriptional regulatory system. Int Rev Cytol 1993; 143: 1-62

7. Auwardt RB, Mudge SJ, Power DA. Transcription factor NF- $\kappa B$ in glomerulonephritis. Nephrology 2000; 5: 71-82.

8. Barnes PJ, Karin M. Nuclear factor $-\kappa B$ : a pivotal transcription factor in chronic inflammatory diseases. N Engl J Med 1997; 336: 1066-1071

9. Morrissey J, Klahr S. Transcription factor NF-kappaB regulation of renal fibrosis during ureteral obstruction. Semin Nephrol 1998;18: 603-611.

10. Massy ZA, Guijarro C, O'Donnell MP, et al. The central role of nuclear factor-kB in mesangial cell activation. Kidney Int Suppl 1999; 71: S76-79.

11. Kitamura M. Adoptive transfer of nuclear factor-kappaBinactive macrophages to the glomerulus. Kidney Int. 2000;57:709-16.

12. Weibel ER. Point Counting Methods. In: Weibel ER. Stereological Methods. vol. 1. Academic Press, London, New York, Toronto, Sydney, San Francisco 1979; 101-159.

13. Barnes PJ, Karin M. Nuclear factor- $\kappa$ B: a pivotal transcription factor in chronic inflammatory diseases. N Engl J Med 1997; 336: 1066-1071.

14. Mezzano SA, Barría M, Droguett MA et al. Tubular NF-kap$\mathrm{paB}$ and AP-1 activation in human proteinuric renal disease. Kidney Int 2001; 60: 1366-1377.

15. Ashizawa M, Miyazaki M, Abe K, et al. Detection of nuclear factor-kappaB in IgA nephropathy using Southwestern histochemistry. Am J Kidney Dis 2003; 42: 76-86.

16. Mudge SJ, Paizis K, Auwardt RB, et al. Activation of nuclear factor-kappa $B$ by podocytes in the autologous phase of passive Heymann nephritis. Kidney Int 2001; 59: 923-931.

17. Sakurai H, Hisada Y, Ueno M, et al. Activation of transcription factor NF-kappa B in experimental glomerulonephritis in rats. Biochim Biophys Acta 1996; 1316: 132-138. 
18. Xie X, Peng J, Huang K, et al. Polydatin ameliorates experimental diabetes-induced fibronectin through inhibiting the activation of NF- $\mathrm{KB}$ signaling pathway in rat glomerular mesangial cells. Mol Cell Endocrinol 2012; 362: 183-189.

19. Wilmer WA, Tan LC, Dickerson JA, et al. Interleukin-1beta induction of mitogen-activated protein kinases in human mesangial cells. Role of oxidation. J Biol Chem 1997; 272: 10877 10881.

20. Guijarro C, Kim Y, Kasiske BL, et al. Central role of the transcription factor nuclear factor-kappa B in mesangial cell production of chemokines. Contrib Nephrol 1997; 120: 210-218.

21. Khachigian LM, Collins T, Fries JW. Nuclear factor-kappa B mediates induction of vascular cell adhesion molecule-1 in glomerular mesangial cells. Biochem Biophys Res Commun 1995; 206: 462-467.

22. Auwardt RB, Mudge SJ, Chen CG, et al. Regulation of nuclear factor kappaB by corticosteroids in rat mesangial cells. J Am Soc Nephrol 1998; 9: 1620-1628.

23. Ruiz-Ortega M, Bustos C, Hernández-Presa MA. Angiotensin II participates in mononuclear cell recruitment in experimental immune complex nephritis through nuclear factor-kappa B activation and monocyte chemoattractant protein-1 synthesis. J Immunol. 1998; 161: 430-439.

24. Guijarro C, Kim Y, Schoonover CM, et al. Lovastatin inhibits lipopolysaccharide-induced NF-kappaB activation in human mesangial cells. Nephrol Dial Transplant 1996; 11: 990-996.

25. Ortego M, Bustos C, Hernández-Presa MA et al. Atorvastatin reduces NF-kappaB activation and chemokine expression in vascular smooth muscle cells and mononuclear cells. Atherosclerosis 1999; 147: 253-261.

26. Massy ZA, Guijarro C, O'Donnell MP, et al. Regulation of mesangial cell proliferation by the mevalonate pathway. Contrib Nephrol 1997; 120: 191-196.

27. O'Donnell MP, Kasiske BL, Kim Y, et al. Lovastatin inhibits proliferation of rat mesangial cells. J Clin Invest 1993; 91: 83-87.

28. Sugiyama H, Savill JS, Kitamura M. Selective sensitization to tumor necrosis factor-alpha-induced apoptosis by blockade of NFkappaB in primary glomerular mesangial cells. J Biol Chem 1999; 274: 19532-19537.

29. Hisada Y, Sakurai H, Sugaya T. Cell to cell interaction between mesangial cells and macrophages induces the expression of monocyte chemoattractant protein-1 through nuclear factor-kappaB activation. Biochem Biophys Res Commun 2000; 269: 309-316.

\section{Address for correspondence}

Prof. Marian Danilewicz MD, PhD

Zamenhofa 5/4

90-431 Łódź, Poland

tel. +48426790191

fax +48426790191

e-mail:marian.danilewicz@umed.lodz.pl 